\title{
DETERMINATION OF SILICA POLYMORPHS AND FELDSPARS IN INDUSTRIAL SAMPLES OF BENTONITE AND PERLITE
}

\author{
Kaza T. and Stamatakis M.G. \\ National and Kapodistrian University of Athens, Department of Geology, Panepistimiopolis, Ano \\ Ilissia, 157 84, Athens, Greece, kaza.triada@hotmail.com, stamatakis@geol.uoa.gr
}

\begin{abstract}
The aim of the present study is to apply a fast and reliable XRD method to identify the percentage of silica polymorphs and feldspars that industrial bentonite and perlite may contain, because these gangue minerals influence the quality of the final products. The current research was implemented by selecting of appropriate almost pure reference samples of bentonite and perlite in which specific amount of silica polymorphs and feldspars was added. The selection of all samples was based on the X-ray diffraction patterns. The synthetic mixtures produced were either with bentonite or perlite with a single added mineral or with two of them in percentages up to $10 \%$. The minerals added to the reference samples were distinguishable in the XRD patterns in different percentages for each mineral added, but also in the two different reference samples. After evaluating of the XRD patterns of a series of samples, it was concluded that the lowest percentage of silica polymorphs and albite that was detected in the reference bentonite was $0.5 \%$ quartz, $1 \%$ cristobalite $10 \%$ opal-CT, and $1 \%$ albite, whereas the percentages for the reference perlite was $1 \%$ quartz, $2 \%$ opal-CT, $1 \%$ cristobalite and $0.5 \%$ albite. This method can be applied to any commercial bentonite and perlite bulk sample to define its purity concerning its silica polymorph and feldspar content.
\end{abstract}

Keywords: Quartz, Opal-CT, Cristobalite, Albite, XRD.

\section{Пєрí $\eta \psi \eta$}

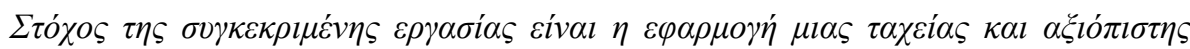

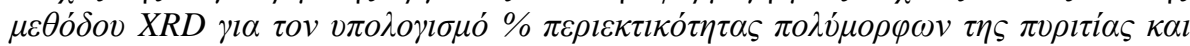

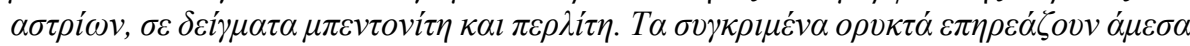

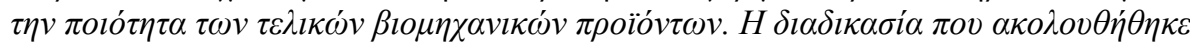

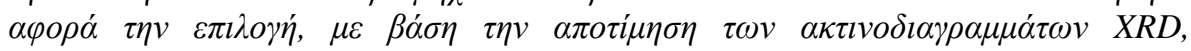

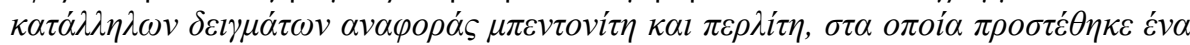

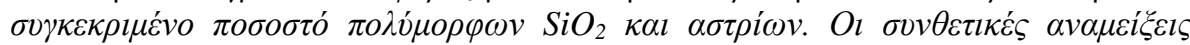

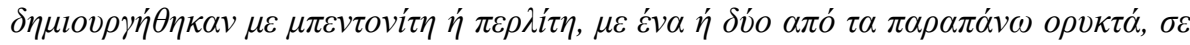

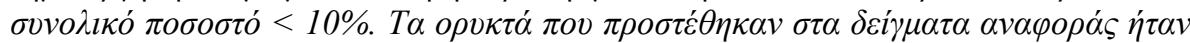

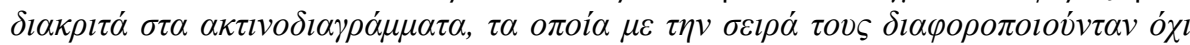

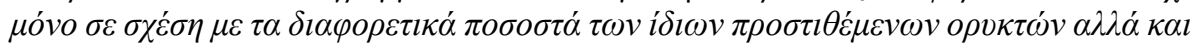

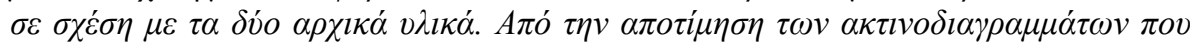

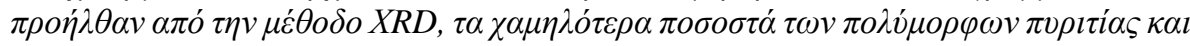

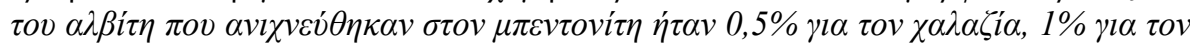

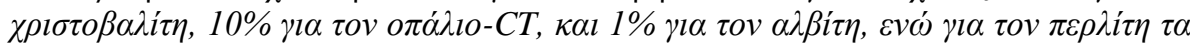

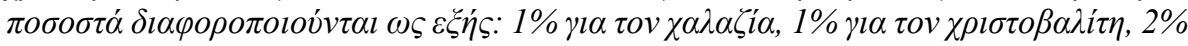




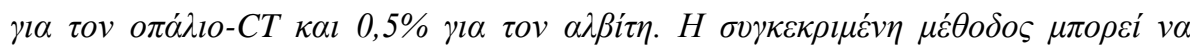

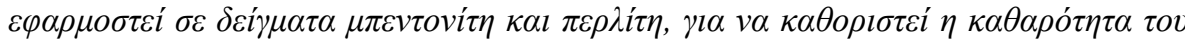

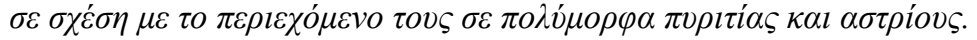

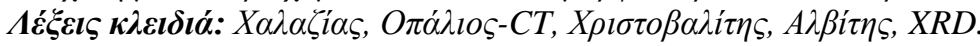

\section{Introduction}

Bentonite and perlite are important industrial minerals since they have qualitative and quantitative characteristics that justify economic interest for their use in a series of industrial and agricultural sectors, trade and generally in human activities (Harben and Kuzvart, 1997).

\subsection{Bentonite}

Bentonite is a rock consisting of aluminosilicate minerals of the group of smectites and its main component is the mineral clay montmorillonite, which is found at a rate of over $80 \%$. Montmorillonite, as well as other minerals of the smectite group, belongs to the phyllosilicates minerals with a 2:1 layer structure and consist of two silica tetrahedral layers between which an aluminum octahedral layer is located (Eisenhour et al., 2009).

Bentonite is used for its rheological, bonding and sorptive properties, as well as its impermeability and large surface area. The main uses include drilling mud, foundry sands, iron ore pelletizing, absorbent granules (litter), various invasive agents, sealants, ingredients in cosmetics, pharmaceuticals and medical applications, fire protection materials, animal food (feed supplement-pelletizing process), additives in ceramics to increase the plasticity, the paper industry and agriculture (Grim et al., 1978).

In Greece, the most important bentonite deposits, with the largest production are in Milos and Kimolos, while minor deposits with no commercial interest occur in Lesvos, Chios and Evros. The deposits of Milos and Kimolos are mainly Ca-bentonites (Francalanci et al., 2008).

Bentonites from Milos (mainly in the eastern and northeastern part of the island) have been formed by transgenic alteration pyroclastic layers, with a composition between Pliocene rhyolite and andesite, which took place in an underwater environment and low temperature conditions (Chrisitids et al., 1995). Bentonite from Milos is mostly calcium with varying percentages of quartz, potassium feldspars and plagioclase. Mineralogical studies have shown that the dominant component of all the deposits is the dioctaedral smectite, while there are also significant percentages of opal, zeolite, alunite, barite, gypsum, sulfides and oxides of iron and titanium (Stamatakis et al., 1996).

In Kimolos the most significant reserves are detected in the northeastern part of the island and include the deposits of Prassa and Loutra (Christidis et al., 1995). The bentonites of Kimolos are mainly calcareous, while it is worth noting that contain significant amounts of cristobalite. The only deposit that is exploited is that of Prassa, since it consists of white high quality bentonite.

Greece conceives the $3^{\text {rd }}$ place in world production of bentonite with extraction of $1.011 .485 \mathrm{t} / \mathrm{yr}$, (USGS 2014). The extraction is mostly in Milos by IMERYS and in smaller quantities in Kimolos by BENTOMINE S.A Company. In a global scale, large bentonite deposits are located in USA and Turkey [ $1^{\text {st }}$ and $2^{\text {nd }}$ producer respectively], and in China, Italy, Spain, Germany, Cyprus, Bulgaria, Australia, Algeria, Morocco and South Africa (Harben and Kuzvart, 1997; USGS, 2014).

\subsection{Perlite}

The term perlite refers to a vitreous acidic volcanic rock which contains $72-76 \% \mathrm{SiO}_{2}$ and $2.6 \% \mathrm{H}_{2} \mathrm{O}^{+}$. The composition is commonly rhyolitic. However some perlites have dacitic or andesitic composition. Most perlites consist almost entirely of a glassy groundmass, in which scattered phenocrysts and microcrystals of quartz, feldspar, biotite and other mafic minerals are found. The presence of phenocrysts, which are found in varying amounts, depreciate their quality since the swelling capacity of the perlite is reduced as the presence of phenocrysts increases (Breese et al., 1994). The age of 
perlite deposits formation is relatively young in geologic time, mostly earlier than Tertiary, since over time lavas undergoes devitrification, partly or completely losing their ability to swell.

Perlite is used in the construction industry as lightweight aggregate and insulation agent, in agricultural applications as soil amendment and in hydroponics, in liquid filtration, in chemical industries, and in environmental applications such as waste filtration, binding of contaminated subsoil, absorption of industrial oil spills and hazardous liquids in contaminated areas (Austin et al., 1995).

Greece ranks $1^{\text {st }}$ in the European and global arena since 2002, with a production of about 876.396 $\mathrm{t} / \mathrm{yr}$ of perlite in 2012, followed by the US and China with production rate reaching only $21 \%$ compared to $38 \%$ in Greece (Bolen, 2013). Perlite is currently mined in Milos Island, in the north coast at Trahilas and in the south coast at Tsigrado by IMERYS SA, and on the islet of Gyali that is located close to Kos and Nisyros islands by the PERLITES AEGEAN SA. In the island of Milos, the formation of perlites is due to the Pliocene volcanic activity and it has created acidic tuffs, tuffites and ignimbrites with an extrusive phase represented by blocks and lava flows of andesite, dacite and rhyolite. In Kos, the volcanic activity is characterized by Upper-Miocene to Pleistocene volcanic products, while Nisyros is a stratovolcano structured by Pliocene volcanic products that consist mainly of andesites and basaltic andesites on which is deposited calcalcaline volcanic products of dacitic-ryodacitic composition in the form of pyroclastic deposits, lava flows and lava structures. Perlite deposits of minor importance occur also in Kimolos, Kos and Lesbos islands.

\section{Materials and Methods}

In order to select the purest minerals to use as reference samples, a series of raw materials were run by XRD, with the exception of perlite extracted from Turkey that was already tested for its purity by Dr D. Alfieris, resources development geologist in IMERYS SA. For bentonite, nine samples derived from different regions of Turkey and Romania was tested, whereas the silica polymorphs and feldspars were derived from different regions of Greece.

\subsection{Materials}

\subsubsection{Bentonite Sample}

The sample selected comes from the area Seyitgazi (39 $26^{\prime} 44^{\prime \prime N} 30^{\circ} 41^{\prime} 38^{\prime \prime}$ E) in central Turkey. The central city of Seyitgazi is $43 \mathrm{~km}$ to the south of the capital of the Eskisehir Province. The area consists of Miocene metamorphic, ophiolitic and carbonate, as well as by Neogene volcanic and sedimentary rocks. More specifically, the background of the given area is represented by Mesozoic carbonate rocks, mélange with sandstones, clays and marls and ophiolites. These rocks are covered by Neogene carbonate rocks, lavas and tuffs (Aydar et al., 2013).

\subsubsection{Perlite Sample}

The perlite sample used was derived from the region Nevsehir ( $\left.38^{\circ} 46^{\prime} 54^{\prime \prime} \mathrm{N}, 34^{\circ} 41^{\prime} 17^{\prime \prime} \mathrm{E}\right)$ a city and the capital of the prefecture of central Turkey. The Nevsehir Plateau belongs to the Central Anatolian Volcanic Province (CAVP) and includes the Cappadocian Volcanic Province (CVP) that is characterized by the development of stratovolcanoes and the presence of thick layers of ignimbrite (Le-Pennec et al., 1994; Lepetit et al., 2007).

\subsubsection{Quartz Samples}

Two quartz samples were analyzed to make the selection of the suitable one. The QUARTZ CRETE sample comes from Kissamos Bay, Chania and it comes from beach sand. The second sample, QUARTZ, comes from quartz veins of milky quartz running through metamorphic rocks of Hymettus Mountain in Attica. 


\subsubsection{Opal-CT Samples}

Based on previous surveys, two samples of opal-CT were tested. The sample OPAL KIM comes from the island of Kimolos and is associated with hydrothermal alteration of volcanic rocks, mainly in the area of Prassa. The sample OPAL EVIA comes from Evia Island and is associated with the formation of stockwork magnesite in ultrabasic rocks (Sample provided by Dr. I. Mitsis).

\subsubsection{Albite Sample}

The albite sample also comes from the island of Crete and more specifically Western Crete, and is associated with the tectonic cover of phyllite-quartzite series (Fytrolakis, 1978).

\subsubsection{Cristobalite Sample}

The sample of cristobalite is a commercial sample imported from Italy, in powder form.

\subsection{Analytical Techniques}

All samples were ground, homogenized, in an agate mile, and analyzed by X-ray diffraction twice, (Siemens Model $5005 \mathrm{X}$-ray diffractometer, $\mathrm{Cu}-\mathrm{Ka}$ rad., $40 \mathrm{kV}, 40 \mathrm{~mA}$, NKUA) and evaluated by use of the EVA 10.0 program.

The methodology initially involved selecting of reference samples for the minerals: quartz, cristobalite, opal-CT and albite, known for their clarity and the absence of impurities. The purity of the samples was defined by evaluating their X-ray diffraction patterns. Afterwards, the corresponding selection of suitable bentonite sample was made with the same procedure, which led to the selection of the appropriate sample with the highest percentage of smectite and low percentage of impurities.

Subsequently, the selection of the reference samples, involves the creation of synthetic mixtures of different percentages of bentonite and perlite with quartz, opal-CT, cristobalite and albite. This process also included the weighing, using the electronic precision balance, and the co-grinding of blends. Finally, the valuation of these X-ray diffraction patterns of the mixtures, allows us to find the lowest percentage of silica polymorphs [quartz, opal-CT, cristobalite] and feldspars [albite].

\section{Results and Discussion}

\subsection{Selection of the reference samples}

\subsubsection{Bentonite}

In Table 1, the mineralogical composition of the bentonite samples studied is shown.

Table 1 - XRD analysis of the bentonite samples studied.

\begin{tabular}{|cccccccccc|}
\hline $\begin{array}{c}\text { Bentonite Sa } \\
\text { mples }\end{array}$ & & \multicolumn{1}{c|}{ Minerals } \\
& QZ & ILL & $\begin{array}{c}\text { CRS/ } \\
\text { OCT }\end{array}$ & MO & VG & ALB & CL & TRD & SN \\
B13352_06 & TR & TR & TR & MJ & & TR & & & \\
B13352_07 & MJ & MD & MD & MD & & MD & & TR & \\
B13352_14 & MD & MD & MD & MJ & & TR & & & TR \\
B13352_40 & MD & TR & MJ & MJ & MJ & MD & & MJ & \\
B07209_03 & MD & MJ & & MD & & MD & MD & & \\
B07225_01 & TR & & MD & MJ & & TR & & & \\
B07226_01 & TR & & MD & MJ & & & & \\
B09416_03 & TR & & MJ & MJ & MD & & & \\
\hline
\end{tabular}


Explanatory Notes: QZ: Quartz, ILL: Illite, CRS/OCT: Cristobalite/Opal-CT, MO: Montmorillonite, VG: Volcanic Glass, ALB: Albite, CL: Clinoptilolite, TRD: Tridymite, SN: Sanidine, MJ: major, MD: medium, TR: trace.

From the above nine bentonite samples, B13352_06 was chosen as appropriate for establishing the laboratory part of the work. Through the process of XRD, it was able to determine the structure and composition of the samples. Therefore, the purity of the sample and the absence of impurities have led us to the given selection.

\subsubsection{Perlite Sample}

The XRD image of the perlite sample reveals that it is exclusively composed of volcanic glass.

\subsubsection{Quartz Sample}

Of the two quartz samples tested, sample QUARTZ CRETE was selected, as the assessment of its $\mathrm{X}$-ray diffraction patterns points us to a high purity sample.

\subsubsection{Opal-CT Sample}

From the two opal-CT samples, the sample: OPAL_EVIA was selected, containing only traces of quartz. By contrast the OPAL_KIM, eventhough rich in opal-CT, it contains higher amounts of quartz and minor tridymite (Figure 1).
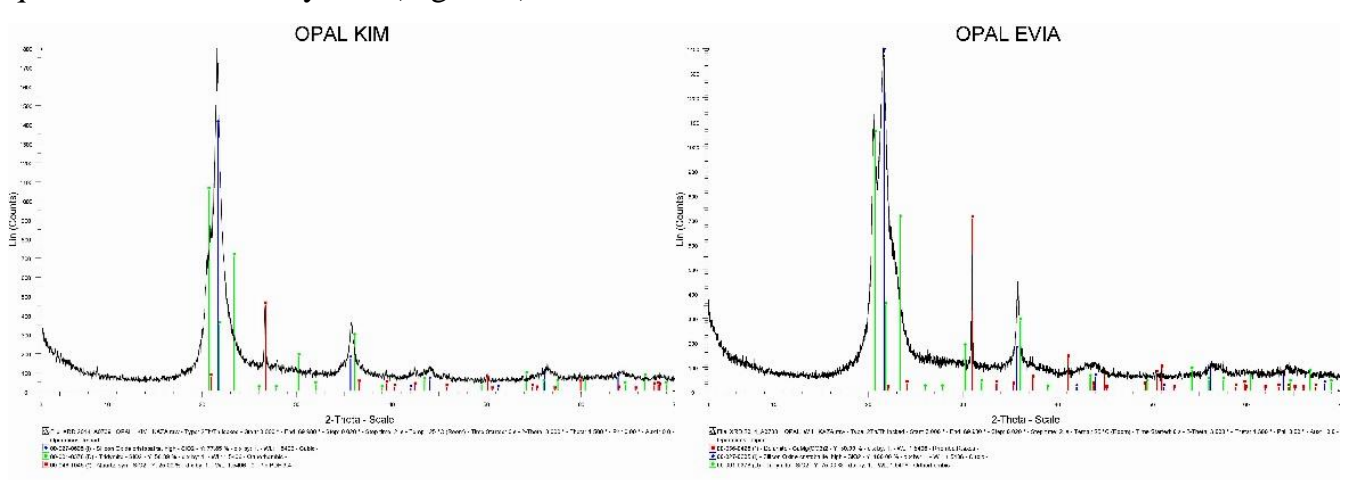

Figure 1 - X-ray diffraction patterns of the opal-CT samples tested.

\subsubsection{Albite Sample}

The feldspar sample selected was identified by XRD as pure albite.

\subsubsection{Cristobalite Sample}

The XRD pattern of cristobalite sample showed that cristobalite is the predominant mineral phase, accompanied by only negligible amount of microcline and quartz.

\subsection{Mixture preparation and XRD analysis}

Mixtures of the two aforementioned reference raw materials with silica polymorphs and albite were prepared. In order to achieve qualities of commercial bentonite and perlite, the percentage of the added minerals was $<10 \%$ in total. The selection of the specific mixtures is shown in Tables 2 and 3.

\subsection{Bentonite Mixtures Results}

Bentonite-Quartz: These blends were prepared by adding of $2 \%$ and $0.5 \% \mathrm{~g}$ of quartz (Figure 2). It is perceived, therefore, that the addition of $2 \%$ quartz creates a characteristic peak that stands out compared to the X-ray diffraction pattern of pure bentonite. In contrast, the addition $0.5 \%$ quartz 
generates a peak that barely stands out from that of pure bentonite, resulting in the rate of $0.5 \%$ quartz being considered the lowest.

Table 2 - Artificial Mixtures of Bentonite.

\begin{tabular}{|c|c|c|c|c|c|}
\hline $\begin{array}{c}\text { Serial } \\
\text { Number }\end{array}$ & $\begin{array}{c}\text { Bentonite } \\
(\%)\end{array}$ & $\begin{array}{c}\text { Quartz } \\
(\%)\end{array}$ & $\begin{array}{c}\text { Cristobalite } \\
(\%)\end{array}$ & $\begin{array}{c}\text { Opal-CT } \\
(\%)\end{array}$ & $\begin{array}{c}\text { Albite } \\
(\%)\end{array}$ \\
\hline 1 & 98 & 2 & & & \\
\hline 2 & 96 & 2 & 2 & & \\
\hline 3 & 98 & & & 2 & \\
\hline 4 & 98 & & 2 & & \\
\hline 5 & 98 & & & & 2 \\
\hline 6 & 99.5 & 0.5 & & & \\
\hline 7 & 90 & & & 10 & \\
\hline 8 & 99 & & 1 & & \\
\hline 9 & 99 & & & & 1 \\
\hline 10 & 99.5 & & & & 0.5 \\
\hline
\end{tabular}

Table 3 - Artificial Mixtures of Perlite.

\begin{tabular}{|c|c|c|c|c|c|}
\hline $\begin{array}{c}\text { Serial } \\
\text { Number }\end{array}$ & $\begin{array}{c}\text { Perlite } \\
(\%)\end{array}$ & $\begin{array}{l}\text { Quartz } \\
(\%)\end{array}$ & $\begin{array}{c}\text { Cristobalite } \\
(\%)\end{array}$ & $\begin{array}{c}\text { Opal-CT } \\
(\%)\end{array}$ & $\begin{array}{c}\text { Albite } \\
(\%)\end{array}$ \\
\hline 1 & 98 & 2 & & & \\
\hline 2 & 96 & 2 & 2 & & \\
\hline 3 & 98 & & & 2 & \\
\hline 4 & 98 & & 2 & & \\
\hline 5 & 98 & & & & 2 \\
\hline 6 & 99.5 & 0.5 & & & \\
\hline 7 & 90 & & & 10 & \\
\hline 8 & 99 & & 1 & & \\
\hline 9 & 99 & & & & 1 \\
\hline 10 & 99 & 1 & & & \\
\hline 11 & 99,5 & & & & 0,5 \\
\hline
\end{tabular}

Bentonite-Opal-CT: These blends were prepared by adding of $10 \%$ and $2 \%$ opal-CT. The addition of $2 \%$ in the first mixing had no difference with the pure bentonite, thus leading to the creation of a new mixture by adding $10 \%$ opal-CT. In the X-ray diffraction pattern of the second mixing, a small difference was observed, concluding that the lower percentage in the case of opal-CT is $10 \%$.

Bentonite-Cristobalite: These blends were prepared by adding of $2 \%$ and $1 \%$ cristobalite. The initial addition of $2 \%$ cristobalite resulted in the creation of a peak with a greater height than that of pure bentonite. Then, a mixture with $1 \%$ cristobalite was created and $1 \%$ was considered the lowest percentage.

Bentonite-Albite: These blends were prepared by adding of $2 \%, 1 \%$ and $0.5 \%$ of albite. This specific mixture exhibited diverse results for each of the two runs at percentages of $0.5 \%$ adding of albite. Controversial results were obtained in a second badge of analyses of the same sample, so we conclude that albite is clearly detectable at the rate of $>1 \%$.

\subsection{Perlite Mixtures Results}

Perlite-Quartz: These blends were prepared by adding of 2\%,1\% and $0.5 \%$ quartz (Figure 3). The process began with the creation of a mixture containing $2 \%$ quartz, resulting in the creation of an 
intense XRD peak at $26.6^{\circ}$ degrees. By contrast, negative results were obtained using the mixture with $0.5 \%$ quartz. The XRD pattern created with this mixture was not different from that of pure perlite. A $3^{\text {rd }}$ mixture was introduced, therefore with $1 \%$ added quartz. In the XRD pattern of this mixture, quartz was detectable.
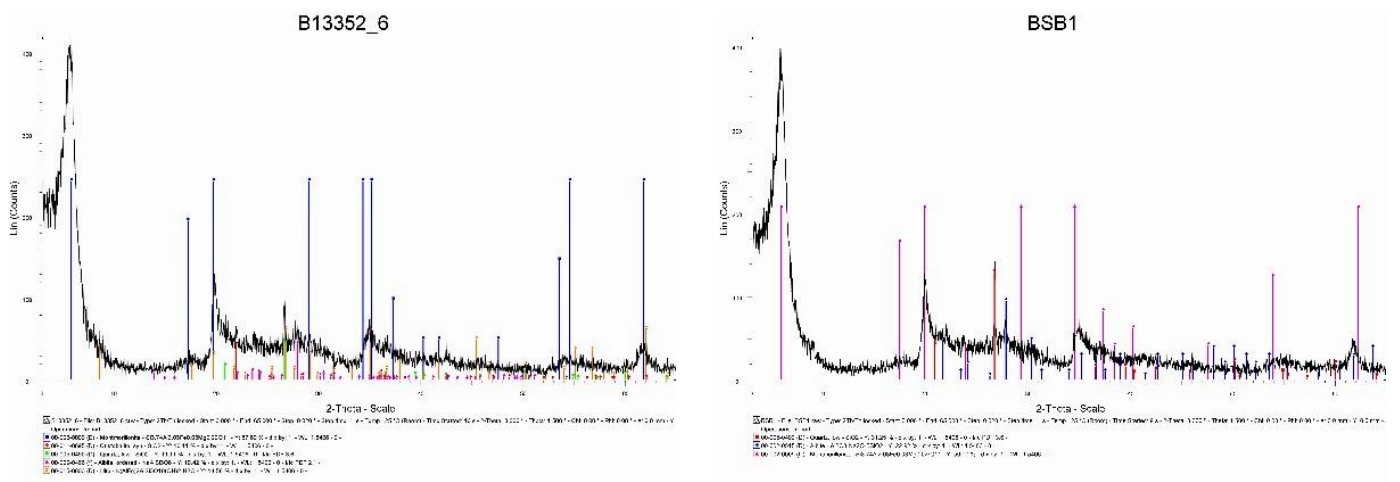

Figure 2 - X-ray diffraction patterns of a) the bentonite sample and b) the mixture of bentonite and quartz.

Perlite-Quartz: These blends were prepared by adding of $2 \%, 1 \%$ and $0.5 \%$ quartz (Figure 3 ). The process began with the creation of a mixture containing $2 \%$ quartz, resulting in the creation of an intense XRD peak at $26.6^{\circ}$ degrees. By contrast, negative results were obtained using the mixture with $0.5 \%$ quartz. The XRD pattern created with this mixture was not different from that of pure perlite. A $3^{\text {rd }}$ mixture was introduced, therefore with $1 \%$ added quartz. In the XRD pattern of this mixture, quartz was detectable.

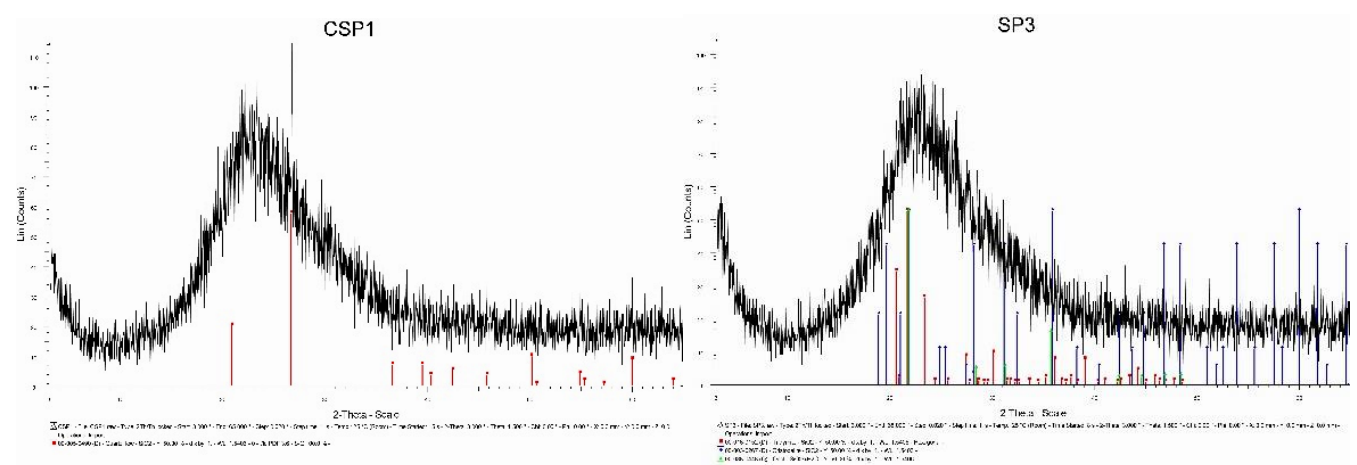

Figure 3- X-ray diffraction patterns of the mixtures of a) perlite and quartz and b) perlite and opal-CT.

Perlite-Opal-CT: These blends were prepared by adding of $10 \%$ and $2 \%$ of opal-CT (Figure 3). In the XRD pattern, when $10 \%$ was added, a sharp change occurs to hump shape. It is more intense in relation to the XRD patterns of pure perlite and perlite with the addition of $2 \%$ opal-CT. However, the lowest detectable percentage of opal-CT addition in perlite was $2 \%$. The semi-crystalline opal and amorphous perlite create an effect in which the difference between XRD patterns is not certain.

Perlite-Cristobalite: These blends were prepared by adding of $2 \%$ and $1 \%$ of cristobalite. The study of the above X-ray diffraction patterns shows clear results, concluding that the lower percentage of cristobalite reaches $1 \%$.

Perlite-Albite: These blends were prepared by adding of $2 \%, 1 \%$ and $0.5 \%$ of albite. The evaluation of the above X-ray diffraction patterns led to the conclusion that the lowest detectable percentage of albite in perlite is $0.5 \%$. 


\section{Conclusions}

In the present work, the identification of significantly low levels of silica polymorphs and feldspars in bentonite and perlite samples was achieved, using XRD techniques. Concerning the bentonite sample, percentages are identified as follows: $0.5 \%$ for quartz, $10 \%$ for the opal-CT, $1 \%$ for cristobalite and $1 \%$ for albite, while the percentages for perlite are to be differentiated as follows: $1 \%$ for quartz, $2 \%$ for opal-CT, $1 \%$ for cristobalite and $0.5 \%$ for albite. The above results are justified by the crystalline nature of quartz and cristobalite, while differentiated in the case of opal-CT, which is semi-crystalline. Still, in line with the material safety data sheet, which determines the quality of perlite in the proportion of crystalline minerals, which must be less than $1 \%$ in quartz. It should also be noted that especially in the case of bentonite, the lowest percentage of opal-CT that was identified is close to $10 \%$, since the insertion of semi-crystalline mineral below this percentage is not shown because of the shape of the XRD pattern. The use of reference artificial samples as prototypes is a fast and accurate method for detection of trace amounts of accessory minerals and the quality control of any perlite and bentonite sample of unknown composition. Similar trials but only with quartz in perlite have been done by McKee et al. (1990). Comparing with Reitveld method the proposed technique is less complicated, since latter requires in each new sample the interference of internal standard of either $\mathrm{ZnO}$ or $\mathrm{Al}_{2} \mathrm{O}_{3}$. Furthermore, the estimation of mineral content, especially in low percentages in samples that contain mainly amorphous phases or smectites is unsafe by Reitveld method. Concerning the estimation of smectite content of bentonite samples using the Cation Exchange Capacity [CEC] method, it is also less accurate in cases of presence of other micro- and mesoporous minerals, i.e., opal-CT, zeolites, other clay minerals, etc. Future plans include the addition and estimation of their detection limit of other undesirable minerals in bentonite, i.e. pyrite, gypsum, alunite, but also clinoptilolite that is frequently determined in some bentonite deposits, like those of Kimolos Island, Bulgaria and Turkey.

\section{Acknowledgments}

The authors would like to express their appreciation to Dr. Dimitris Alfieris, IMERYS SA (former S\&B Industrial Minerals SA), for providing us all bentonite and perlite samples. Additionally, we would like to thank Dr. George Economou, IGME, for sample preparation, and Dr. Ioannis Mitsis UoA, for helping in XRD analysis.

\section{References}

Austin, G.S. and Barker, J.M., 1995. Production and Marketing of perlite in the western United States, In: Tabilio, M. and Dupras, D.L., eds., Proceedings, 29th Forum on the Geology of Industrial Minerals, California Division of Mines and Geology, Special Publication, 110, 39-68.

Aydar, E., Çubukcu, H.E., Şen, E. and Akin, L., 2013. Central Anatolian Plateau, Turkey: incision and paleoaltimetry recorded from volcanic rocks, Department of Geological Engineering, Hacettepe University, Ankara, Turkey, Turkish Journal of Earth Sciences, 22, 739-746.

Bolen, W.P., 2013. Perlite Mininig Engineering, U.S. Geological Survey: National Minerals Information Center, 72-73.

Breese, R.O.Y. and Barker, J.M., 1994. Perlite, Industrial Minerals and Rocks, 6th ed. Society for Mining, Metallurgy and Exploration, Littleton, Colorado, Carr, L., ed., 735-749.

Christidis, G.E., Scott, P.W. and Marcopoulos, T., 1995. Origin of the Bentonite Deposits of Eastern Milos, Aegean, Greece: Geological, Mineralogical and Geochemical Evidence, Clays and Clay Minerals, (43), 63-77.

Eisenhour, D.D. and Brown, R.K., 2009. Bentonites - Versatile Clays: Bentonite and Its Impact on Modern Life, ELEMENTS, 5(2), 83-88.

Francalanci, L., Vougioukalakis, G.E. and Fytikas, M., 2008. Petrology and Volcanology of Kimolos and Polyegos volcanoes within the context of the South Aegean Arc, Greece. Geol. Soc. Am., Spec. Paper (481), 33-65. 
Fytrolakis, N., 1978. Contribution to the geological survey of Crete, Bull. Geol. Soc., Greece, XIII/2, 101-115 (in Greek).

Grim, R.E. and Güven, N., 1978. Bentonites: Geology, Mineralogy, Properties and Uses. Developments in Sedimentology, 24, Amsterdam, Elsevier scientific publishing company.

Harben, P.W. and Kuzvart, M., 1997. Industrial minerals - global geology, Industrial Minerals Information Ltd. (IMIL), Worcester Park, Surrey, UK. Annex.

Le-Pennec, J.L., Bourdier, J.L., Froger, J.L., Temel, A., Camus, G. and Gourgaud, A., 1994 Neogene ignimbrites of the Nevsehir plateau, Elsevier, Amsterdam, Netherlands.

Lepetit, P., Viereck- Goette, L. and Gurel, A., 2007. Neogene Stratigraphyn of the Nevsehir Plateau, Cappadoca, Turkey, Geological Background in Field Guide to the Excursion on the Geology of the Nevsehir Plateau and the historical cultural.

McKee, Ch., Renault, J. and Barker J., 1990. Quantitative analysis of quartz in perlite by X-ray diffraction, Prepr. Soc. Min. Eng. Aime, Soc of Mining Engineers of Aime, Littleton, CO, (USA), 11-166.

Stamatakis, M., Lutat, U., Regueiro, M. and Calvo, P.J., 1996. Milos-The mineral island, Industrial Minerals, No 341.

USGS, 2014. Mineral Commodity Summaries, Clays, 44. 